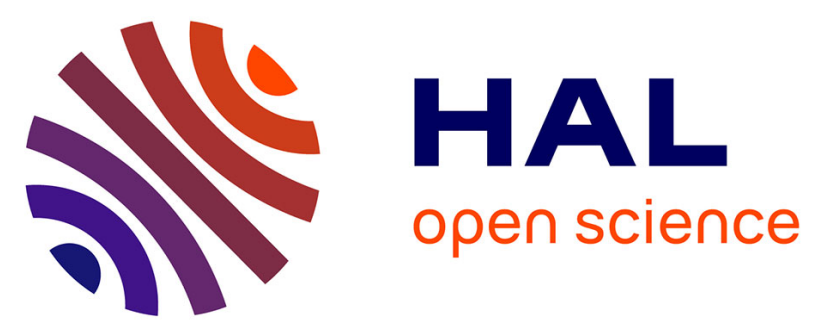

\title{
Drought sensitivity of pastures related to soil and landform in the eastern Amazon
}

François Laurent, René Poccard-Chapuis, Sophie Plassin, Marie-Gabrielle

Piketty, Ali Fadhil Hasan, François Messner, Reinis Osis, Florent Perrier, Ling

Zi Huang

\section{To cite this version:}

François Laurent, René Poccard-Chapuis, Sophie Plassin, Marie-Gabrielle Piketty, Ali Fadhil Hasan, et al.. Drought sensitivity of pastures related to soil and landform in the eastern Amazon. Journal of applied remote sensing, 2021, 15 (02), 10.1117/1.JRS.15.024514 . hal-03248934

\section{HAL Id: hal-03248934 \\ https://hal.science/hal-03248934}

Submitted on 3 Jun 2021

HAL is a multi-disciplinary open access archive for the deposit and dissemination of scientific research documents, whether they are published or not. The documents may come from teaching and research institutions in France or abroad, or from public or private research centers.
L'archive ouverte pluridisciplinaire HAL, est destinée au dépôt et à la diffusion de documents scientifiques de niveau recherche, publiés ou non, émanant des établissements d'enseignement et de recherche français ou étrangers, des laboratoires publics ou privés.

\section{(1) (1) $\$$}

Distributed under a Creative Commons Attribution - NonCommercial - NoDerivatives 44.0 
François Laurent, René Poccard-Chapuis, Sophie Plassin, Marie-Gabrielle Piketty, Ali Fadhil Hasan, François Messner, Reinis Osis, Florent Perrier, Ling-Zi Huang, 2021: Drought sensitivity of pastures related to soil and landform in the eastern Amazon. J. Appl. Rem. Sens. 15(2), doi: 10.1117/1.JRS.15.024514

corresponding author: francois.laurent@univ-lemans.fr 


\begin{abstract}
Livestock in the Amazon is mainly limited by the lack of forage biomass production in the dry season. The sensitivity of pasture to drought depends on pasture management and on certain natural factors that enable the grass cover to stay green for longer under low rainfall. The sustainability of livestock production systems depends on identifying these natural factors to make better use of their forage production potential without consuming additional water resources or resorting to deforestation. We built an index of pasture dependence on rainfall at the beginning of the dry season by calculating the slope of the linear regression between the MODIS enhanced vegetation index (EVI) and monthly cumulative rainfall obtained from the Tropical Rainfall Measuring Mission (TRMM). The index was calculated in Paragominas municipality. A 15-year time series (2000-2014) was used to assess the sensitivity of pasture to drought. A map of geomorphological units was overlaid on the index map to check whether the soil and the landform influence drought sensitivity at a large scale. Drought resistance was shown to be higher in lowland areas with loamy sand with a shallow groundwater table and on plateaus covered by fertile sedimentary clay. The escarpments with a ferruginous duricrust and mottled clay were shown to be the most sensitive to drought. These results underline the importance of natural factors in pasture productivity in tropical humid areas.
\end{abstract}

\title{
Keywords
}

Pasture, Cattle farming, Drought, Soil, Landform, Amazon.

\section{Introduction}

Soil water availability during the dry season is a major limit to livestock production in the southern and eastern Amazon. Nearly half the Amazon biome has a "monsoon" climate, termed tropical "wet and dry" climate according to the Köppen classification ${ }^{1}$, which includes a dry season. On a typical Amazonian beef cattle farm, cattle graze pasture all year round ${ }^{2,3}$, have no access to stored forage in the form of hay or silage, and are consequently depend entirely on seasonal biomass growth ${ }^{4}$. Uneven seasonal rainfall distribution in the rainy and dry seasons affects grass photosynthesis over the course of the year, which in turn, can affect pasture productivity and animal carrying capacity, i.e. the capacity of pasture to support a given number of animal units $(A U)^{5}$. A study in eastern Amazonia showed a two thirds decrease in pasture transpiration rates during the dry season due reduced photosynthetic activity ${ }^{6}$. Another study in western Amazonia found that the average carrying capacity of a mixed massai grass-forage peanut pasture in the dry season was $50 \%$ lower (1.8 AU.ha' $\left.{ }^{1}\right)$ than in the rainy season (3.6 AU.ha $\left.{ }^{-1}\right)^{7}$. What is more, the intensity and frequency of prolonged periods of abnormally low rainfall have increased in recent decades in the region ${ }^{8,9}$, as evidenced by the dramatic events in 2005, 2010 and 2015 at Amazon scale ${ }^{10-12}$. Amazonian cattle farmers are increasingly concerned by grass water stress ${ }^{13,14}$. This may get worse in the future due to global and regional climate changes resulting from deforestation ${ }^{15}$. The sustainability of livestock breeding depends on potential soil water storage to enable forage production without irrigation or resorting to deforestation to maintain or increase the production of forage. In this context, large scale maps showing pasture sensitivity to drought provided by remote sensing are extremely useful.

Some assessments of grassland or rangeland biomass production in the dry season based on remote sensing showed a strong correlation between the MODIS vegetation indices and averaged gross primary production. These studies analyzed the sensitivity of pastures to drought and showed that biomass production is influenced by precipitation variability in space and over time, especially during the dry season. A study conducted in the Pampa biome showed that the Moderate Resolution Imaging Spectroradiometer normalized difference vegetation index (MODIS NDVI) was a function of the net primary production of aboveground forage ${ }^{16}$. In a large watershed in the Great Plains in United States, a strong correlation was demonstrated between the NDVI averaged over the growing season and the annual productivity of grassland provided by the Soil Survey Geographic database ${ }^{17}$. A 
study conducted nearby evaluated the sensitivity of MODIS vegetation indices for grassland to drought severity ${ }^{18}$. In Northern Mexico, another study in savanna grassland and desert scrub quantified seasonal and interannual changes in vegetation greenness using the MODIS enhanced vegetation index $(\mathrm{EVI})^{19}$. In three Amazon pasture sites with similar annual rainfall $(2,000-2,200 \mathrm{~mm})$ and a similar dry season (4-5 months), Huete et al. found that the MODIS EVI was closely linked to rainfall and declined by as much as $25 \%$ in the dry season in response to water stress ${ }^{20}$. These authors validated MODIS EVI values with measurements of EVI from eddy flux towers that clearly depicted seasonal photosynthetic activity patterns ${ }^{20}$. Pastures in wet and dry tropical areas are subject to a decline in photosynthetic activity at the beginning of the dry season due to increasing water stress ${ }^{21}$. This is termed "brown-down" trend and is visible by remote sensing.

Biomass production in the dry season depends not only on precipitation but also on water stored in the soil. Soil moisture controls the vegetation dynamics by converting precipitation into available water for vegetative growth. However, few studies have analyzed the impact of the spatial variability of soil moisture on pasture biomass production at a large scale ${ }^{5,22}$. Soil texture influences soil moisture ${ }^{23-25}$ and consequently plant activity ${ }^{22-24}$, while landforms partially control drainage and consequently soil moisture ${ }^{29,30}$. An understanding of the effect of soil and landform on the response of vegetation to drought is thus crucial to understand physiological variations in plants. However, despite the importance of the sensitivity of livestock pasture to drought, little is known about its spatial variability as a function of the soil and the landform. Understanding how unevenly distributed natural factors influence biomass production, by taking sensitivity to drought into account, will enable identification of the most suitable areas for grazing.

The aim of the present study was to assess the sensitivity of pasture biomass production to drought using remote sensing and spatial analysis. Our specific objectives were to: (1) define a remote sensing method integrating rainfall and photosynthetic activity to assess drought sensitivity, (2) map drought sensitivity at a scale of thousands of $\mathrm{km}^{2},(3)$ investigate if soil and landform combined in geomorphological units, influence sensitivity to drought. Our study will help insure the sustainability of livestock farming through better use of these factors to produce forage without water withdrawal and deforestation.

\section{Material and Methods}

Study area

The study was conducted in Paragominas, a $19,342 \mathrm{~km}^{2}$ municipality in northeastern Amazonia (Figure 1). Paragominas is located in the 'arc of deforestation', a mosaic of degraded primary forest, pasture, cropland, tree plantations, and patches of secondary forest. The climate is wet and dry, according to the Köppen classification, with a marked dry season ${ }^{31}$. Average annual rainfall in the city of Paragominas in the period from 2000 to 2014 was $1,938 \mathrm{~mm}$ measured by the daily rain gauge at weather station number 247005 (Hidroweb, Rede Hidrometeorológica Nacional, Sistema Nacional de Informações sobre Recursos Hídricos, Brazil), and estimated at 2,006 mm by the Tropical Rainfall Measuring Mission (TRMM) ${ }^{32}$. The dry season is defined as the period with consecutive monthly rainfall less than $100 \mathrm{~mm}$, which, at these latitudes, is less than potential evapotranspiration ${ }^{33}$. The dry season in Paragominas lasts six months, from June to November (Figure 2). A significant northsouth rainfall gradient exists within the municipality: mean cumulative rainfall in the dry season ranges from $294 \mathrm{~mm}$ in the southern part to $690 \mathrm{~mm}$ in the northern part (TRMM data ${ }^{32}$ ) (Figure 3). Landforms consist of northwestward inclining dissected plateaus at elevations ranging from 110 to $220 \mathrm{~m}$ above sea level separated by valleys whose bottoms range from 45 to $80 \mathrm{~m}$ asl. and can reach several kilometers in width. The eastern part of the municipality is a plain ranging from 50 to $100 \mathrm{~m}$ $\mathrm{as}^{34}$. The transitions between the plateaus and the valleys and the plain are steep slopes that form escarpments. The most frequent soils are Ferralsols (FAO taxonomy) or Oxisols (USDA taxonomy), deeply weathered red or yellow soils that are common in the humid tropics. The soil texture in the 
study area depends to a great extent on the nature of the bedrock and landform ${ }^{34}$ : on the plateaus covered by a sedimentary layer of Belterra clay, the soils are clayey Ferralsols; on the upper slopes of the valleys, they are gravel soils formed by the dismantling of the duricrust; in the plain, the valley bottoms and lower slopes (here collectively referred to as lowlands), they are loamy sand Ferralsols formed by weathering of sandstone ${ }^{34,35}$. At the beginning of the dry season, the lowlands still have a shallow groundwater table near the surface, whereas the plateaus and the slopes of the valleys dry out earlier. The natural vegetation is tropical rainforest. However, $45 \%$ of the study area has been deforested since the 1960s, mainly for cattle ranching, and since the 2000s, also for soybean and maize cropping ${ }^{36}$. The pastures are mainly located in the lowlands because rivers are needed to water the animals ${ }^{37,38}$.

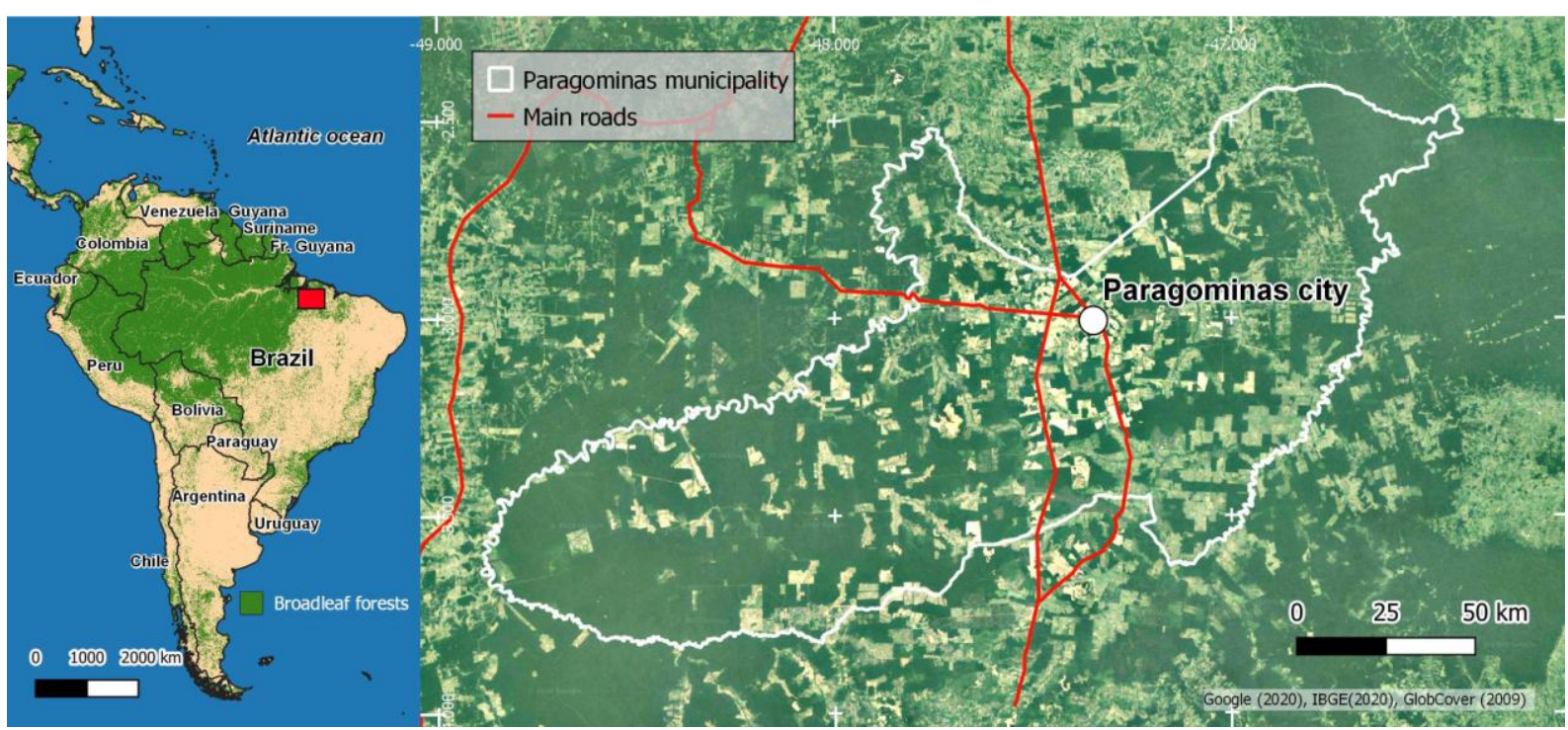

Figure 1: Location and land cover in Paragominas municipality

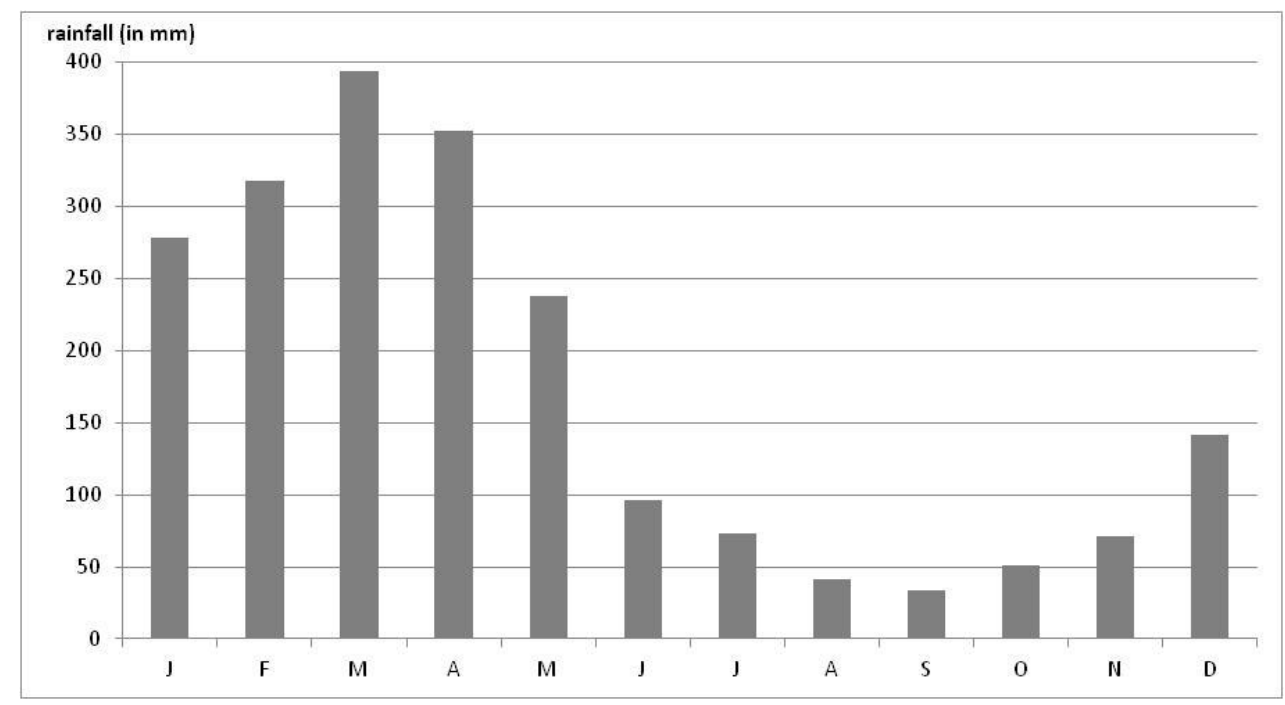

Figure 2: Mean monthly rainfall, Paragominas city, 2000-2014 (source: TRMM) 


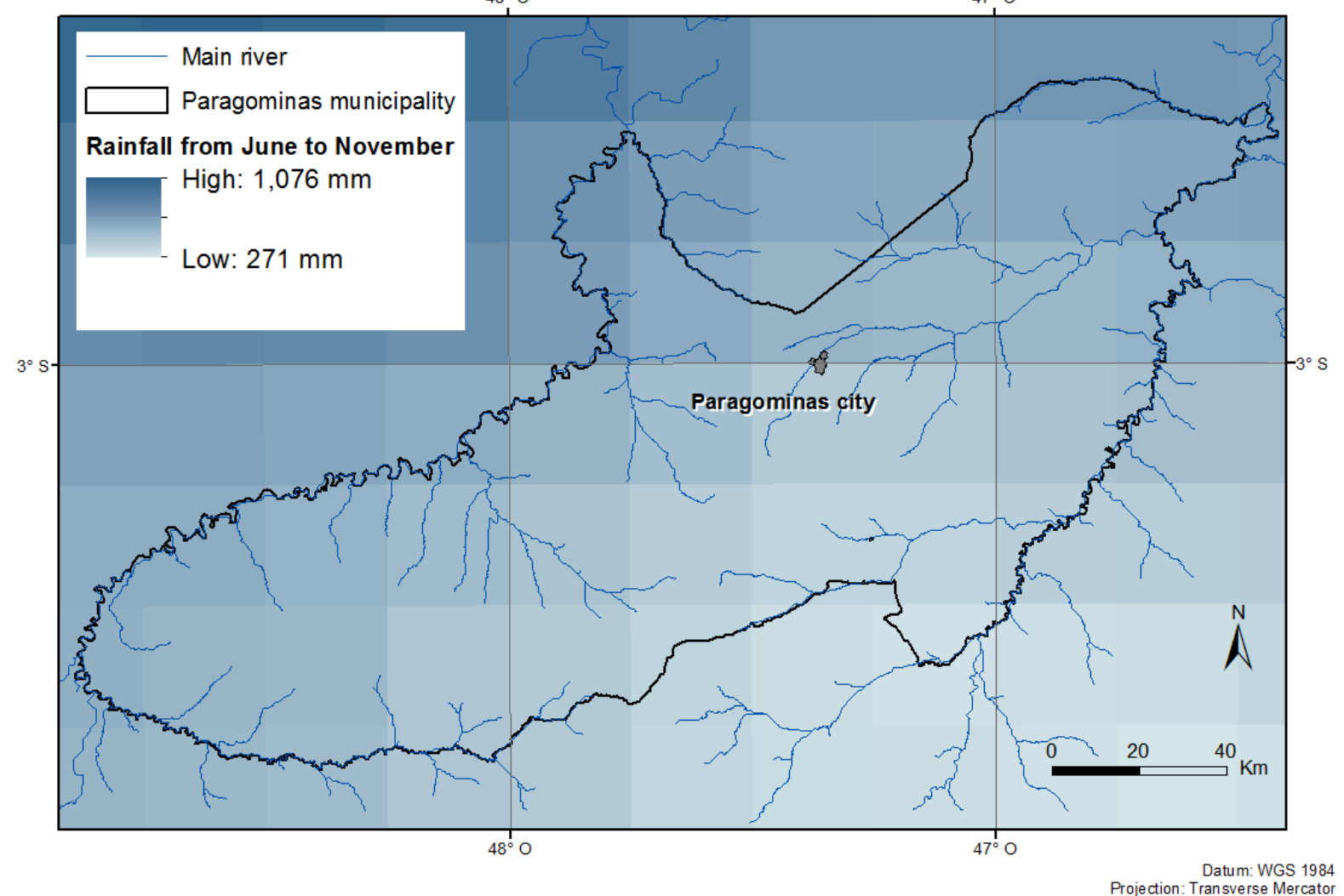

Figure 3: Mean cumulative rainfall in the dry season for the period 2000-2014 (source: TRMM)

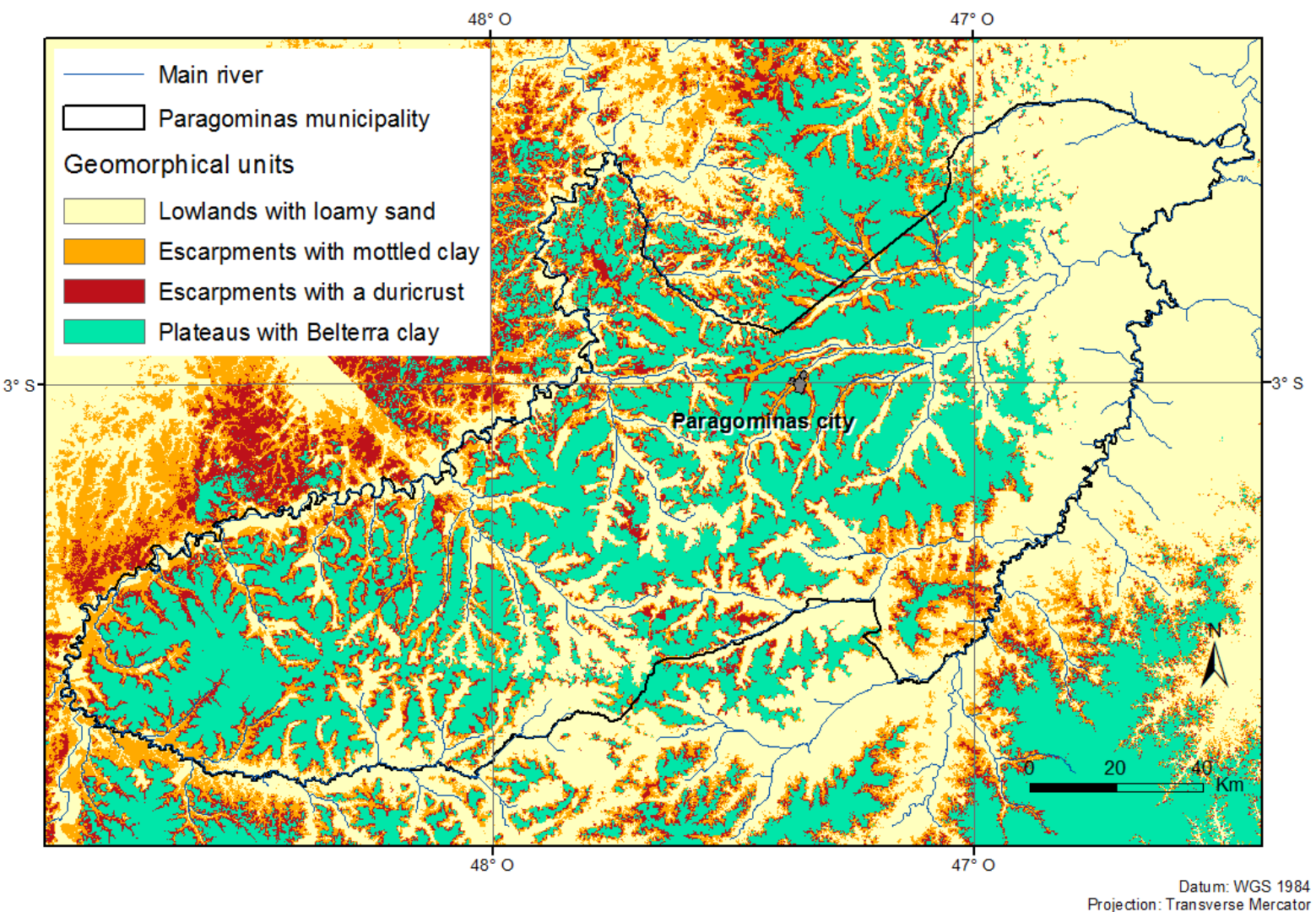

Figure 4: Geomorphological units (source Laurent et al., 2016) 


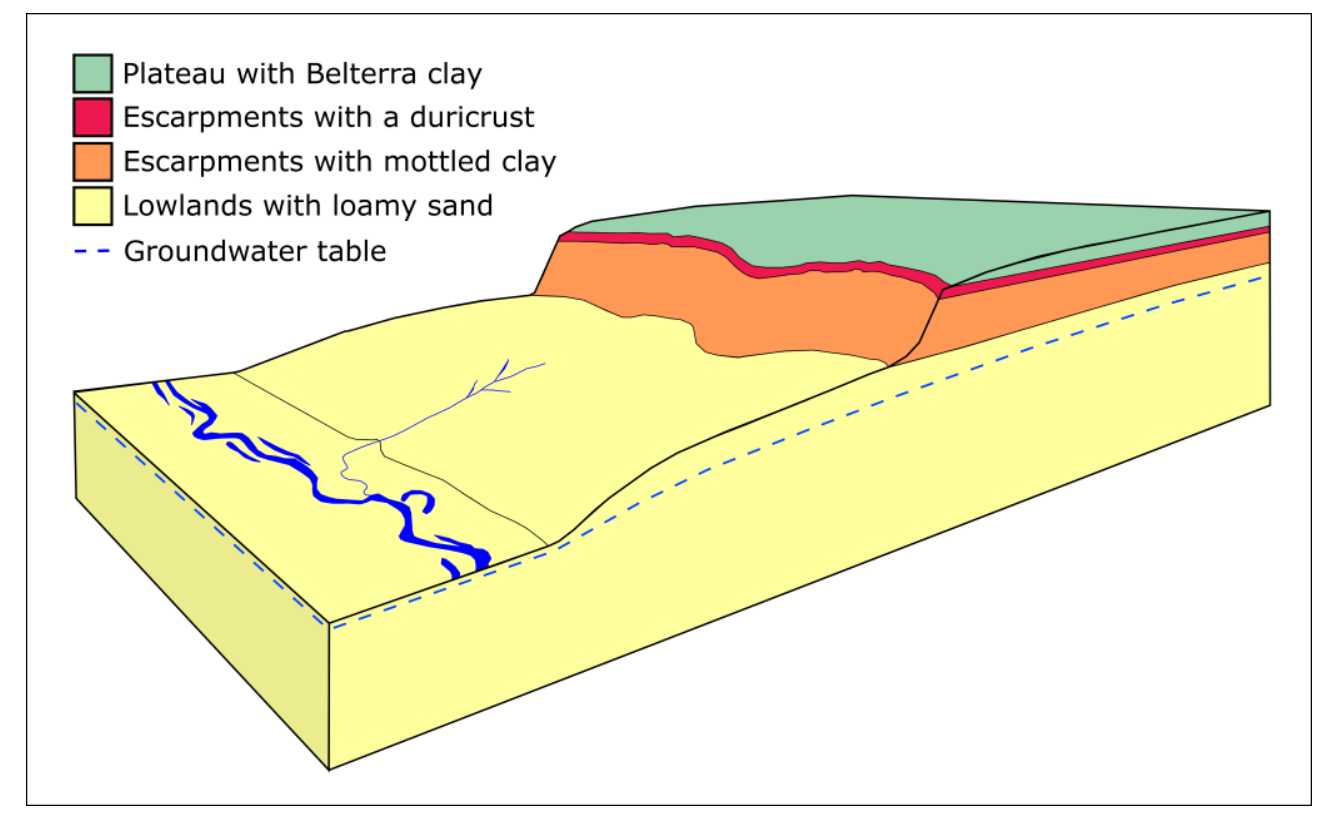

Figure 5: Organization of the geomorphological units in the landscape in the Paragominas area

Data

- Geomorphological units

To analyze the relation between the soil, the landform and sensitivity of pasture to drought, we used the map of soil classes based on the texture of the topsoil layer and the bedrock, at a 1:100,000 scale created by ${ }^{34}$ (Figure 4). The type of soil is closely linked to the topographic location ${ }^{35,39}$ and to water saturation, defining four types of geomorphological units (Figure 4 and Figure 5): well drained plateaus with Belterra clay, well drained escarpments that form the upper slopes of the valleys with gravel soils, well drained escarpments with mottled clay, and valleys and the plain with loamy sand and a shallow groundwater table ${ }^{37}$.

- Rainfall data

The Tropical Rainfall Measuring Mission (TRMM) Multi-satellite Precipitation Analysis (TMPA) provides rainfall data at 0.25 degree spatial resolution ${ }^{31,32}$, or about $27.8 \mathrm{~km}$ in the study area. There are 42 TRMM cells in the study area. TRMM data were acquired at monthly intervals for the period 2000-2014 ${ }^{32}$. Mantas et al. (2015) showed that TRMM data were highly correlated with in situ rainfall data, especially at monthly scale ${ }^{42}$. In Paragominas, data recorded by rain gauge station $n^{\circ} 247005$ (Rede Hidrometeorológica Nacional, Sistema Nacional de Informações sobre Recursos Hídricos, Brazil) revealed slight differences, particularly from June to September: TRMM underestimated monthly rainfall by $5 \%$ over the study period.

- Photosynthetic activity

MODIS on board NASA Terra and Aqua satellites provides images at 1 to 2 day intervals at a spatial resolution of $250 \mathrm{~m}^{43}$. The high temporal resolution and the wide range of wavelengths (36 spectral bands) mean the MODIS products reliably identify vegetation dynamics. The MOD13Q1 product aggregates data at 16-day intervals. The enhanced vegetation index (EVI) was chosen for this study. Compared to NDVI, EVI uses blue bands in addition to red and NIR bands. EVI improves sensitivity in high biomass regions while minimizing the influence of the soil and the atmosphere ${ }^{44}$. Monthly EVI means were calculated for each year in the period 2000-2014. 
- $\quad$ Land use

Annual land use was obtained from MODIS $\mathrm{EVI}^{43}$. Initially, five classes were identified: bare urban soil, forest, annual crops, pasture, and deforested land. To estimate the land use for each year, a set of data made up of the time series of the EVI images associated with phenological metrics calculated using TIMESAT software were used as inputs for the statistical model. The algorithm of the classifier was Random Forest, whose parameters were optimized using the caret package in $R^{45,46}$. Postprocessing using filtering techniques was applied to remove classification errors. First, the isolated pixels of the crop class were replaced by the majority land use in a $3 \times 3$ convolution window. Secondly, border effects corresponding to confusion between two adjacent classes were corrected using the following approach. The intersection of the dilation by mathematical morphology of two adjacent land use classes made it possible to select the pixels located at the edge of each class. At the resolution of MOD13Q, these are found at the crop/forest interface and the most often mixed pixels misclassified by Random Forest as pasture. These mixed pixels were removed from the pasture class $^{47}$. The precision of final classification results is good; this is generally not allowed by the MODIS land use product (MCD12Q1), whose aim is to establish a global scale classification. Only the "pasture" class was kept, while the other land use classes were masked. In 2014, pastureland accounted for $4,415 \mathrm{~km}^{2}$, corresponding to $22.8 \%$ of the total surface area of the municipality, with 70,640 MODIS pixels classified as pasture.

\section{Method}

The EVI of pastureland was averaged at a monthly time step from 2000 to 2014 to reveal its dynamics over the year. From 2000 to 2014, the monthly EVI was associated pairwise with monthly TRMM and their correlation calculated to identify the dependence of pasture photosynthetic activity on rainfall.

Linear regressions were performed at the beginning of the dry season between MODIS EVI and TRMM monthly values for each MODIS pixel to calculate the slope of the regression and to evaluate the influence of rainfall on photosynthetic activity. This index detects the strength of the "browndown" process in the dry season. The steeper the slope of the linear regression, the more the EVI depends on rainfall during the dry season and the lower the drought resistance of the pasture. Only the first four months of the dry season were used because they represent the soil moisture depletion phase (Figure 2) and show how grass resists drought by exploiting soil moisture. In the city of Paragominas, June is the first month in the year when rainfall falls below $100 \mathrm{~mm}$ (the monthly threshold used in the Amazon region to define the dry season) and when hydric stress could occur. Reduced rainfall continues until September. From October on, increasing rainfall increases photosynthetic activity independent of the sensitivity of pasture to drought. We therefore selected the period from June to September to analyze the "brown-down" trend. From 2000 to 2014, we obtained 60 pairs of values (15 years $\times 4$ months) of monthly rainfall and the mean monthly EVI for each pixel.

The inclusion of rainfall in the index, which is a linear regression between EVI and rainfall, determines whether factors other than rainfall have an impact on vegetation activity. We tested the hypothesis that sensitivity to drought depends on soil and landform, which together control available water. The map of the regression slope between the MODIS EVI and the TRMM precipitation was then overlaid on the geomorphological units. A non-parametric analysis of variance (ANOVA) with the KruskalWallis method and Wilcoxon pairwise comparisons tests were performed on the classes of geomorphological units with the slope of the linear regression.

To identify variations in EVI dynamics between greater or lesser droughts at the beginning of the dry season, the slope was processed based on the four years with the driest periods from June to September. The years with the driest dry season were identified based on the standardized 
precipitation index ${ }^{48}$ calculated for the four first months of the dry season. The 4-month SPI index compares total precipitation over the 4-month period under review with total precipitation for the same 4-month period in all the years for which records are available. The years with the driest JuneSeptember periods (hereafter termed the driest years) were 2004, 2005, 2006 and 2010, with respectively 196, 149, 195 and $175 \mathrm{~mm}$ compared to an average of $269 \mathrm{~mm}$ of rain for the whole period 2000-2014. A non-parametric ANOVA was applied to check if the distribution of the regression slope still differentiated the driest years among the geomorphological units and the differences were analyzed.

\section{Results}

EVI dynamics over the year

The EVI fluctuated considerably over the year. The highest photosynthetic values were measured from January to March, the months with the heaviest rainfall, followed by a decline in photosynthesis until October associated with the decrease in rainfall, EVI then increased from October on with the return of rain (Figure 6). Mean monthly EVI was correlated with mean monthly rainfall, $\mathrm{R}^{2}=0.55$ ( $n=180 ; p$-value < 2.2e-16) (Figure 7) thereby demonstrating the dependence of EVI on rainfall, which is common in tropical wet and dry climates. This dynamics reflects the drop in pasture productivity in the dry season thereby reducing the availability of forage for cattle.

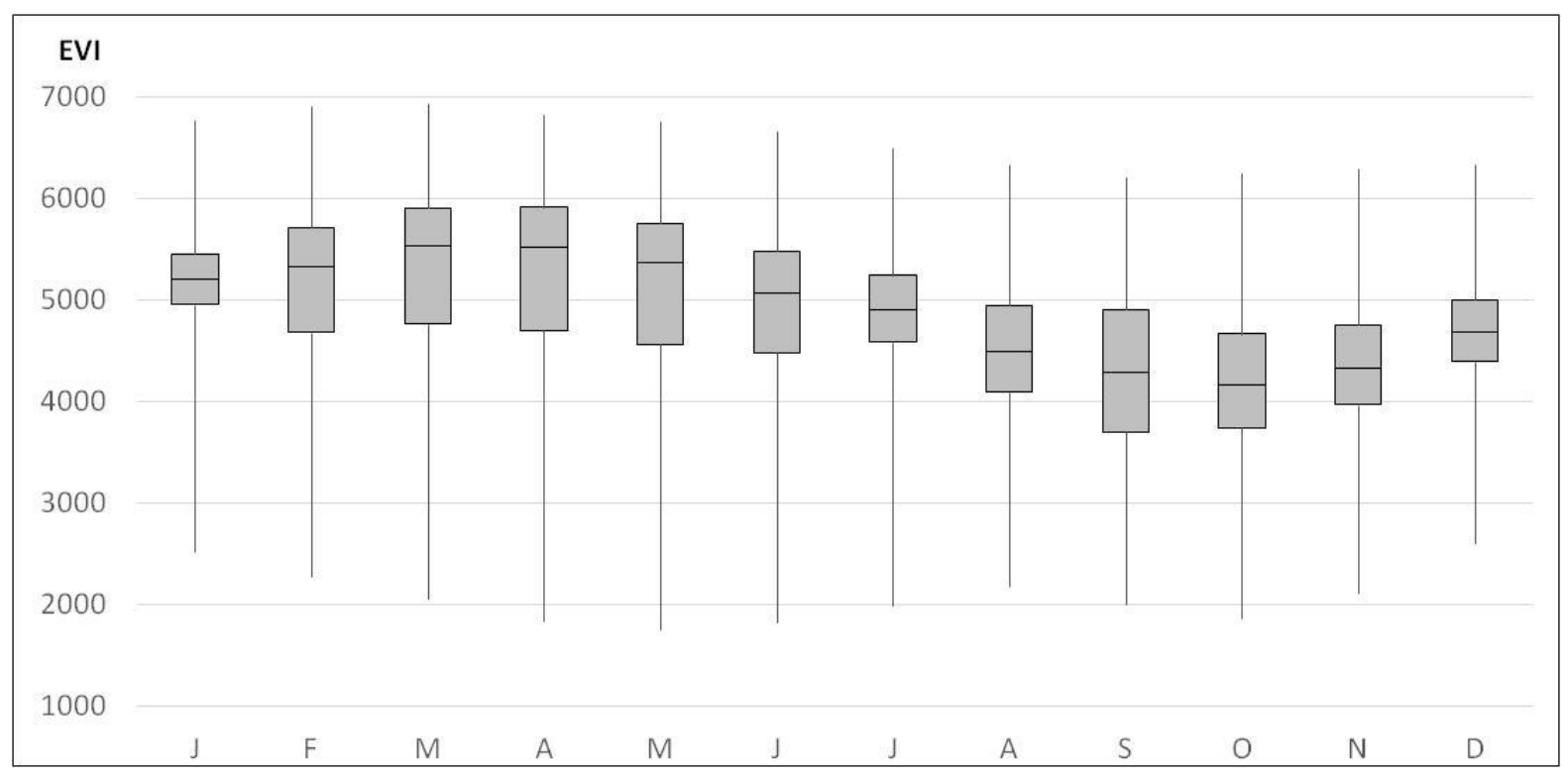

Figure 6: Mean monthly EVI of the pixels with pasture for the period 2000-2014 


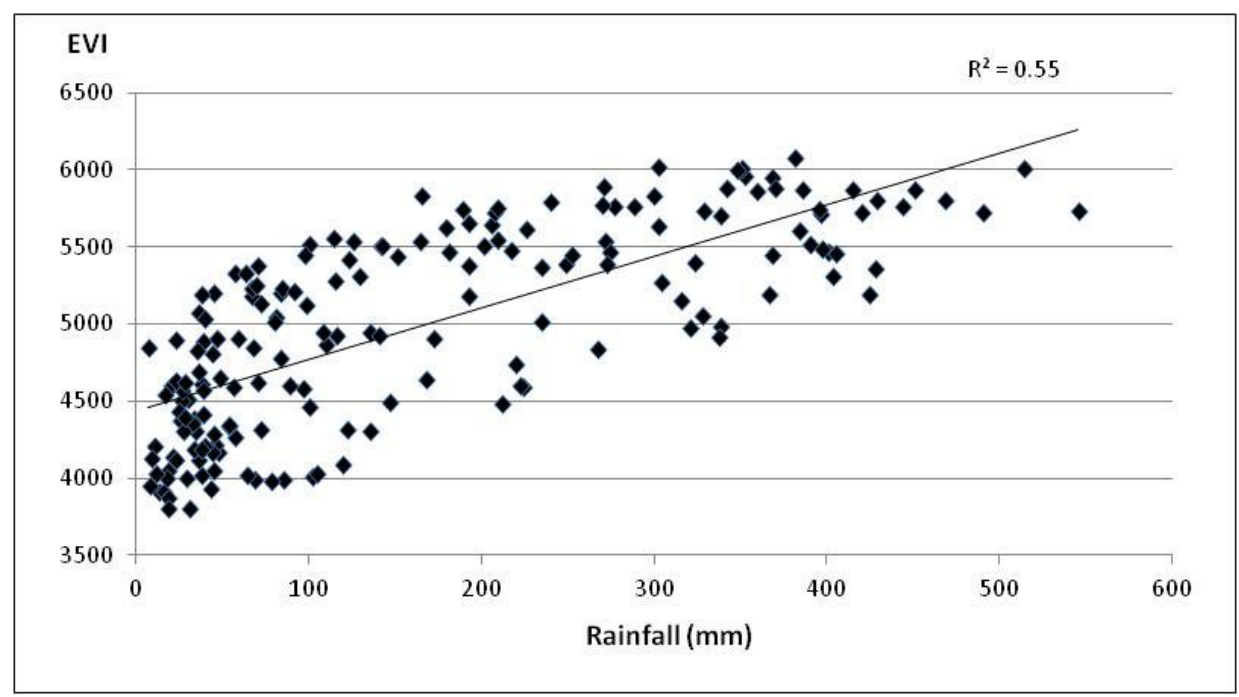

Figure 7: Monthly EVI in relation with monthly rainfall (source: TRMM), period 2000-14

The slope of the linear regression between the MODIS EVI and the TRMM precipitation at the beginning of the dry season revealed no dependence on the north-south rainfall gradient in the dry season (Figure 3 and Figure 8). Crossing TRMM values (Figure 3) and the regression slope (Figure 8), revealed no significant correlation between the slope of the linear regression (the intensity of the "brown-down" trend) of each TRMM cell and mean rainfall from June to September (the correlation coefficient of each cell gave a mean of -0.083 for the 42 TRMM cells representing the study area). Thus, the drought sensitivity index did not spatially depend on rainfall during the dry season. Consequently, the high spatial variability of the index depends on other factors.

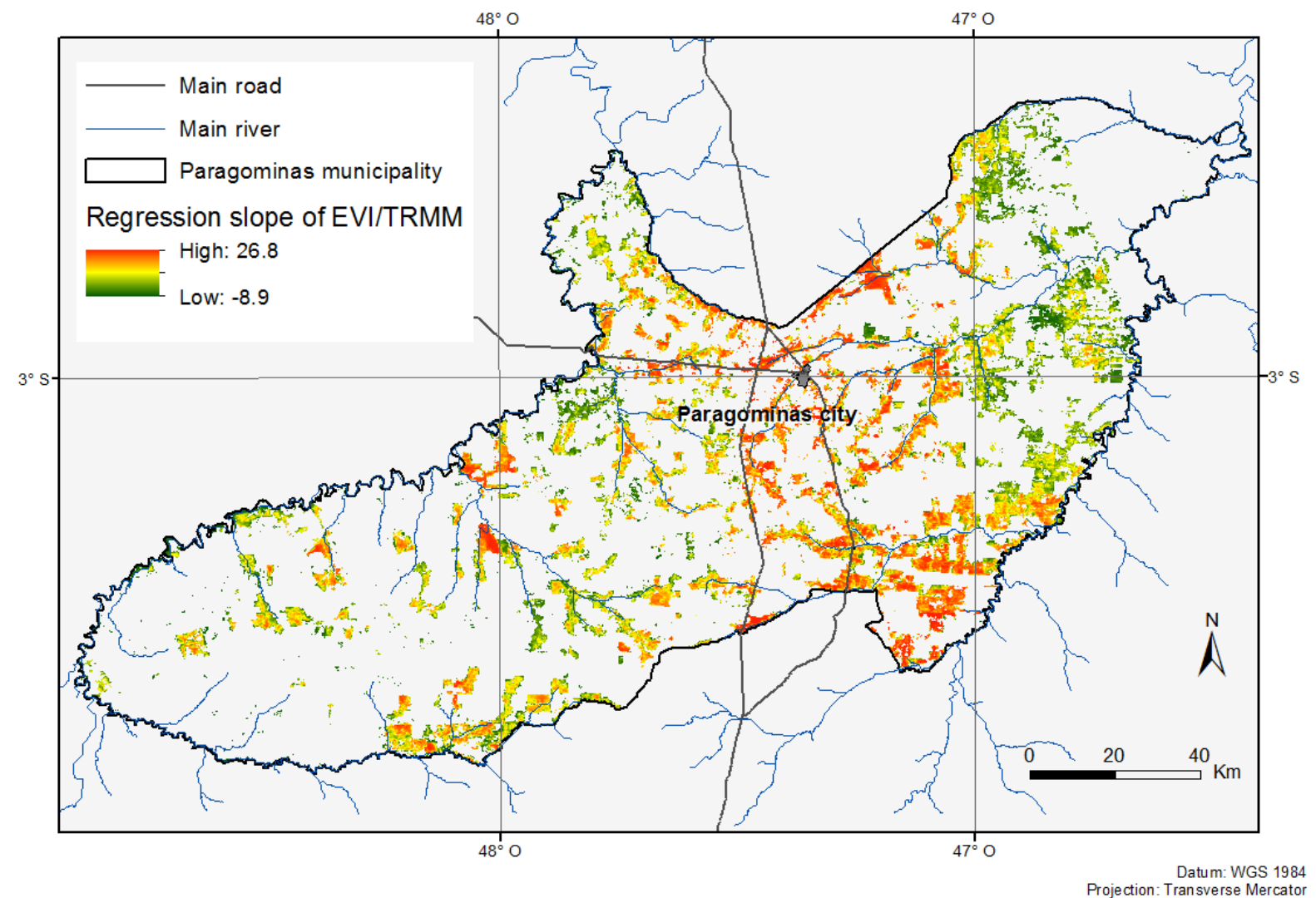

Figure 8: Map of pasture sensitivity to drought based on the linear regression between MODIS EVI and TRMM monthly values, from June to September, for the period 2000-2014 
Drought sensitivity and geomorphological units

Spatial overlay of the pasture area from the MODIS EVI 2014 image classification and geomorphological units showed that pasture areas are concentrated in lowlands with loamy sand. Loamy sand accounts for $65.9 \%$ of total pasture area, higher than the proportion of this geomorphological unit in the municipality as a whole (38.9\%).

Despite high variance, the means of the regression slope between geomorphological units differed significantly (Table 1 and Figure 9). The Kruskal-Wallis rank sum test between the mean slope of the linear regression of the geomorphological units showed a chi-squared $=911.38, d f=3, p$-value $<$ 2.2e-16. Pairwise comparisons using the Wilcoxon rank sum test showed significant differences between each geomorphological unit, except between lowland with loamy sand and plateaus with Belterra clay, where the difference was not significant ( $p$-value $=0.23$ ). Lowlands with loamy sand and plateaus with Belterra clay were less sensitive to drought, as they presented the lowest slope of the linear regression (Table 1 and Figure 9). The escarpments with duricrust were more dependent on rainfall; this relation was even more accentuated with mottled clays, which dry out faster (Table 1 and Figure 9).

\begin{tabular}{|c|c|c|c|c|c|}
\hline Geomorphological unit & $\mathrm{n}$ & Mean slope & Variance slope & Mean $\mathrm{R}^{2}$ slope & Group \\
\hline Lowlands with loamy sand & 43845 & 7.28 & 17.67 & 0.246 & a \\
\hline Escarpments with mottled clay & 9032 & 8.72 & 19.74 & 0.266 & $\mathrm{~b}$ \\
\hline Escarpments with a duricrust & 4617 & 8.13 & 19.76 & 0.280 & c \\
\hline Plateaus with Belterra clay & 8829 & 7.40 & 24.05 & 0.255 & $\mathrm{a}$ \\
\hline$P$ & $<2.2 \mathrm{e}-16$ & & & & \\
\hline
\end{tabular}

Table 1: Pairwise comparison of slopes between EVI and rainfall across geomorphological units. $\mathrm{R}^{2}$ shows the representativeness of the EVI/TRMM regression slope for each pixel 


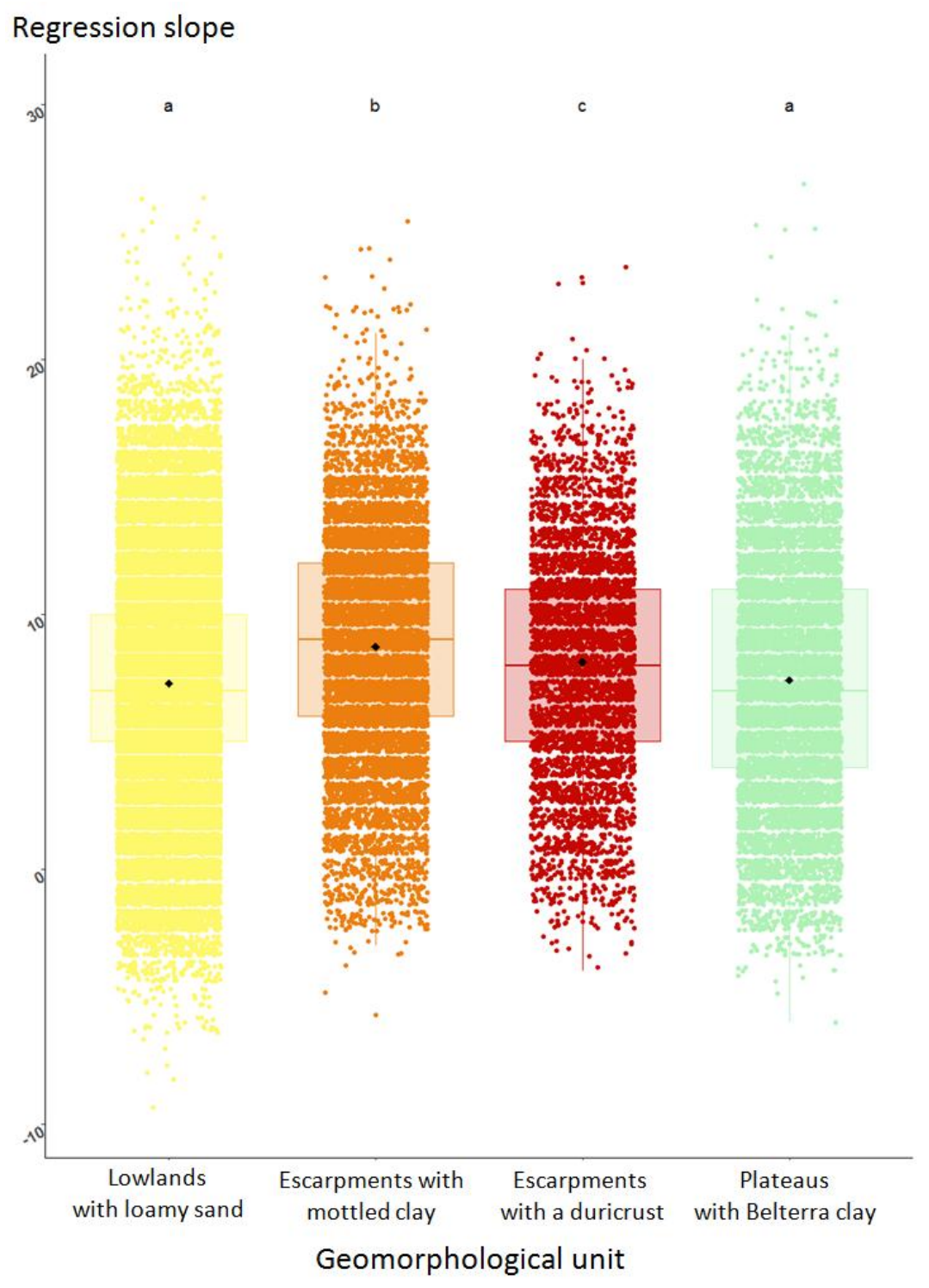

Figure 9: Distribution of the slope of the linear regression, 2000-2014, according to the geomorphological unit; the higher the value of the mean slope, the more sensitive the pasture to drought.

\section{Drought sensitivity in the driest years}

The four years with the driest dry season (2004, 2005, 2006 and 2010) ranked in the same order between geomorphological units (Table 2) as the mean for the period 2000-2014, but with higher regression slope values for all the geomorphological units. This could be attributed to higher sensitivity to drought in the driest years due to the rapid depletion of stored soil water. Variance was also greater in these years, indicating more spatial variability of drought sensitivity. Similarly, the $\mathrm{R}^{2}$ was lower, showing more variability of drought sensitivity over time.

\begin{tabular}{|c|c|c|c|c|c|}
\hline Geomorphological unit & $\mathrm{n}$ & Mean slope & Variance slope & Mean $\mathrm{R}^{2}$ slope & Group \\
\hline Lowlands with loamy sand & 43845 & 8.90 & 53.02 & 0.197 & a \\
\hline Escarpments with mottled clay & 9032 & 10.70 & 54.81 & 0.205 & $\mathrm{~b}$ \\
\hline Escarpments with a duricrust & 4617 & 9.99 & 53.97 & 0.187 & $\mathrm{c}$ \\
\hline Plateaus with Belterra clay & 8829 & 9.53 & 53.80 & 0.175 & a \\
\hline $\mathrm{p}$ & $<2.2 \mathrm{e}-16$ & & & & \\
\hline
\end{tabular}

Table 2: Pairwise comparison of slopes between $\mathrm{EVI}$ and rainfall across geomorphological units in the driest years: 2004, 2005, 2006 and 2010 


\section{Discussion}

In Brazil, more than $95 \%$ of cattle are grass fed ${ }^{49}$. It is thus urgent to support grazing based livestock systems by providing methods to assess sensitivity to drought over large areas of pasture at low cost as well as by identifying the natural factors able to reduce the sensitivity of pasture to drought.

Our results show that the slope of the linear regression EVI/TRMM can be used to assess the drought sensitivity of pasture, and to assess if the spatial variability of photosynthetic activity is due to other factors than rainfall. In our study area, the slope of the linear regression revealed the impacts of the soil and landform factors.

Grimaldi et al. showed that available water capacity in the Amazon depends to a great extent on soil texture $^{50}$. Sand usually has a lower water storage capacity than clay but our results showed loamy sand to be as sensitive to drought as Belterra clay. The impact of soil texture thus appeared to be offset by topographic position. In the lowlands with loamy sand, pasture roots were shown to access water in the shallow groundwater table, explaining why lowland pastures were more drought resistant than escarpments. The plateaus covered with Belterra clay were also shown to be drought resistant. As the plateaus are well drained, a shallow groundwater table cannot explain their drought resistance. On the other hand, their soil texture (Belterra clay) has a higher available water capacity and better physical and chemical fertility ${ }^{51}$ that enhance the development of grass roots ${ }^{13,52}$ and consequently improve their resistance to drought. The escarpments (mottled clay or duricrust) are less fertile ${ }^{51}$ and are well drained due to their steep slopes. The grass dries out rapidly with a decrease in rainfall, making these areas less favorable for the production of forage in the dry season. Comparison of the driest years (Table 2) and the period 2000-2014 (Table 1) shows their ranking remained the same regardless of the severity of the drought.

Figure 8 shows the meridian gradient with higher sensitivity around the city of Paragominas and along the main roads in the central meridian area. One possible explanation is the extent of the drought sensitive geomorphological units (the escarpments), but these units are not significantly more present in the area close to the roads: the escarpments represent $16 \%$ of the area less than $20 \mathrm{~km}$ from the main roads and $17 \%$ of more than $20 \mathrm{~km}$. Another hypothesis is that there is less degraded pasture with invasive shrub located close to the roads ${ }^{38}$ : the more accessible the pasture is to agricultural machinery, the easier it is to manage and to eliminate invasive ligneous plants ${ }^{37}$. Ligneous plants are less sensitive to drought and maintain a higher EVI in the dry season which could explain the meridian gradient around the city of Paragominas and along the main roads.

Our results showed varying suitability for pasture among geomorphological units. The differences in drought sensitivity among the geomorphological units could enable a land-use strategy that limits pasture to cleared areas in the lowlands and on the plateaus, these two landforms being most suitable for permanent grazing by cattle. As the escarpments are more sensitive to drought, in addition to their higher risk of erosion, they are less suitable for cattle farming and should be reserved for forest conservation or restoration.

Mapping the drought sensitivity index could be a tool to monitor the adaptation of farming systems to climate change at local and regional scale. In a context of more frequent droughts, forage production and cattle stocking rates drop drastically in escarpments with steep slopes. Therefore, the accumulation of dry matter in pasture increases the risk of fire. During severe droughts, dry pasture cover in the Amazon is vulnerable to fires that also burn large areas of the neighboring forests, as evidenced in recent years ${ }^{12}$. A better management of pasture related to the soil and landform could reduce the fire risks.

Limitations and future work 
The drought sensitivity index map was not validated by soil moisture measurements. There are no insitu monitoring stations in the study area. However, remote sensing based methodologies could be used in future research, and would be more efficient than field measurements to represent the spatial variability of soil moisture over a large $\operatorname{area}^{53}$ like that considered in the present study. Both active and passive remote sensing methods can be used to monitor temporal and spatial variations in soil moisture conditions. Radarsat-1 SAR and Envisat-1 ASAR have been shown to efficiently map soil moisture ${ }^{25,54-57}$. The linear regression between the MODIS EVI and monthly cumulative rainfall obtained from TRMM could be therefore compared to the slope of soil moisture depletion during the first months of the dry season.

Photosynthetic activity depends to a certain extent on grazing intensity. Some plots may have a low EVI despite high productivity simply because they are overgrazed. For this reason, it is difficult to link photosynthetic activity with forage production, although this is indispensable to estimate the aptitude of pastures to meet a certain stocking rate in the dry season. Future work should thus measure the impact of grazing on the EVI.

Mapping sensitivity to drought is limited by spatial resolution and by the structure of the landscape that comprises both small and large patches. Only homogeneous land use patches more than 6.25 ha in size were detected. In reality, the pixels classified as pasture could contain a mix of other land use types, particularly when the pasture contains trees. The influence of neighboring plots on the resistance of pasture to drought was not included in our analysis.

We chose a 4-month period from June to September to show the phase of soil water depletion because it is typical of the study area. However, we did not account for the fact that, in some years, the dry season may start either earlier or later and that the length of the period with less rainfall can vary. In other areas, the months with a downward trend in precipitation and with monthly precipitation of less than $100 \mathrm{~mm}$ may differ from the months in Paragominas. Thus, it would be difficult to map drought sensitivity using the same reference period for very large areas, e.g. for a Brazilian state in which the period of soil water depletion is not the same everywhere.

The identification of geomorphological units in the landscape was relatively simple in our study area due to a strong correlation between soil and landform factors. In other geomorphologic contexts, more continuous transitions between geomorphological units could hinder the analysis of the influence of natural factors on drought sensitivity.

\section{Conclusions}

The results of this study suggest that the empirical EVI-TRMM relationship is an appropriate index to account for the impacts of water stress on pasture photosynthetic activity in space and over time at a large scale. MODIS and TRMM data are available cost free. The transferability of the method should be tested by applying it in other areas of similar size in a wet and dry tropical climate. We showed notably that the slope of the linear regression can be used as an indicator for monitoring pasture drought over large areas. We applied the method in the Brazilian municipality of Paragominas and showed that drought sensitivity varied across the study area depending on soil and landform factors: lowlands with a shallow groundwater table and plateaus covered by fertile soils were shown to be the least sensitive to drought, and steep slopes to be the most sensitive. Almost all IPCC models predict increasing seasonal water deficit in southern and eastern Amazonia in the coming decades ${ }^{58}$, mapping the drought sensitivity index will be a useful way to monitor the adaptation of farming systems to climate change at local and regional scale. 


\section{Acknowledgments}

The research was conducted with the financial support from the French Agence Nationale de la Recherche, through the ECOTERA project (ECOefficiences et développement TERritorial en Amazonie brésilienne; ANR-13-AGRO-0003).

\section{References}

1. R. S. Oliveira et al., "Hydraulic redistribution in three Amazonian trees," Oecologia 145(3), 354363 (2005) [doi:10.1007/s00442-005-0108-2].

2. C. C. Cerri et al., "Assessing the carbon footprint of beef cattle in Brazil: a case study with 22 farms in the State of Mato Grosso," J. Clean. Prod. 112, 2593-2600 (2016) [doi:10.1016/j.jclepro.2015.10.072].

3. Dias-Filho, M.B. and Andrade, C.M.S., "Pastagens no trópico úmido," Documentos 241, Embrapa Amazônia oriental (2006).

4. T. T. S. Siqueira and M. Duru, "Economics and environmental performance issues of a typical Amazonian beef farm: a case study," J. Clean. Prod. 112, 2485-2494 (2016) [doi:10.1016/j.jclepro.2015.10.032].

5. I. Numata et al., "Regional Characterization of Pasture Changes through Time and Space in Rondônia, Brazil," Earth Interact. 11(14), 1-25 (2007) [doi:10.1175/El232.1].

6. D. C. Nepstad et al., "The role of deep roots in the hydrological and carbon cycles of Amazonian forests and pastures," Nature 372(6507), 666-669 (1994) [doi:10.1038/372666a0].

7. C. M. S. de Andrade et al., "Grazing management strategies for massaigrass-forage peanut pastures: 3. definition of sward targets and carrying capacity," Rev. Bras. Zootec. 35(2), 352-357 (2006) [doi:10.1590/S1516-35982006000200004].

8. J. A. Marengo et al., "Recent Extremes of Drought and Flooding in Amazonia: Vulnerabilities and Human Adaptation," Am. J. Clim. Change 02(02), 87-96 (2013) [doi:10.4236/ajcc.2013.22009].

9. J. A. Sena et al., "Extreme Events of Droughts and Floods in Amazonia: 2005 and 2009," Water Resour. Manag. 26(6), 1665-1676 (2012) [doi:10.1007/s11269-012-9978-3].

10. J. A. Marengo et al., "The Drought of Amazonia in 2005," J. Clim. 21(3), 495-516 (2008) [doi:10.1175/2007JCLI1600.1].

11. J. A. Marengo et al., "The drought of 2010 in the context of historical droughts in the Amazon region: DROUGHT AMAZON 2010," Geophys. Res. Lett. 38(12), n/a-n/a (2011) [doi:10.1029/2011GL047436].

12. C. H. L. Silva Junior et al., "Fire Responses to the 2010 and 2015/2016 Amazonian Droughts," Front. Earth Sci. 7, 97 (2019) [doi:10.3389/feart.2019.00097].

13. T. Beloni et al., "Morphological and physiological responses and the recovery ability of Paspalum accessions to water deficit and waterlogging," Grass Forage Sci. 72(4), 840-850 (2017) [doi:10.1111/gfs.12281].

14. A. M. Mazzetto et al., "Improved pasture and herd management to reduce greenhouse gas emissions from a Brazilian beef production system," Livest. Sci. 175, 101-112 (2015) [doi:10.1016/j.livsci.2015.02.014].

15. C. A. Nobre et al., "Land-use and climate change risks in the Amazon and the need of a novel sustainable development paradigm," Proc. Natl. Acad. Sci. 113(39), 10759-10768 (2016) [doi:10.1073/pnas.1605516113].

16. G. Grigera, M. Oesterheld, and F. Pacín, "Monitoring forage production for farmers' decision making," Agric. Syst. 94(3), 637-648 (2007) [doi:10.1016/j.agsy.2007.01.001].

17. Y. Gu, B. K. Wylie, and N. B. Bliss, "Mapping grassland productivity with 250-m MODIS NDVI and SSURGO database over the Greater Platte River Basin, USA," Ecol. Indic. 24, 31-36 (2013) [doi:10.1016/j.ecolind.2012.05.024]. 
18. Y. Gu et al., "A five-year analysis of MODIS NDVI and NDWI for grassland drought assessment over the central Great Plains of the United States," Geophys. Res. Lett. 34(6) (2007) [doi:10.1029/2006GL029127].

19. L. A. Méndez-Barroso et al., "Seasonal and interannual relations between precipitation, surface soil moisture and vegetation dynamics in the North American monsoon region," J. Hydrol. 377(1-2), 59-70 (2009) [doi:10.1016/j.jhydrol.2009.08.009].

20. A. R. Huete et al., "Amazon rainforests green-up with sunlight in dry season," Geophys. Res. Lett. 33(6) (2006) [doi:10.1029/2005GL025583].

21. M. L. Meirelles et al., "Evapotranspiration and plant-atmospheric coupling in a Brachiaria brizantha pasture in the Brazilian savannah region: Evapotranspiration and plant-atmospheric coupling," Grass Forage Sci. 66(2), 206-213 (2011) [doi:10.1111/j.1365-2494.2010.00777.x].

22. P. Jiang et al., "Diverse response of vegetation growth to multi-time-scale drought under different soil textures in China's pastoral areas," J. Environ. Manage. 274, 110992 (2020) [doi:10.1016/j.jenvman.2020.110992].

23. W. Rawls et al., "Infiltration and soil water movement," in Handbook of hydrology, D. Maidment, Ed., McGraw-Hill, Inc., New York (1993).

24. W. Rawls and D. Brakensiek, "Prediction of Soil Water Properties for Hydrologic Modeling," in Watershed Management in the Eighties, pp. 293-299, ASCE (1985).

25. H. S. Srivastava et al., "Large-Area Soil Moisture Estimation Using Multi-Incidence-Angle RADARSAT-1 SAR Data," IEEE Trans. Geosci. Remote Sens. 47(8), 2528-2535 (2009) [doi:10.1109/TGRS.2009.2018448].

26. J. Joiner et al., "Global relationships among traditional reflectance vegetation indices (NDVI and NDII), evapotranspiration (ET), and soil moisture variability on weekly timescales," Remote Sens. Environ. 219, 339-352 (2018) [doi:10.1016/j.rse.2018.10.020].

27. C. Papagiannopoulou et al., "Vegetation anomalies caused by antecedent precipitation in most of the world," Environ. Res. Lett. 12(7), 074016 (2017) [doi:10.1088/1748-9326/aa7145].

28. T. Chen et al., "A global analysis of the impact of drought on net primary productivity," Hydrol. Earth Syst. Sci. 17(10), 3885-3894 (2013) [doi:10.5194/hess-17-3885-2013].

29. A. Calver, K. J. Beven, and D. R. Weyman, "Modelling hillslope and channel flows," in Spatial Analysis in Geomorphology, pp. 197-218, Methuen (1972).

30. K. J. Beven and M. J. Kirkby, "A physically based, variable contributing area model of basin hydrology," Hydrol Sci Bull 24, 43-69 (1979).

31. V. Dubreuil et al., "Les types de climats annuels au Brésil : une application de la classification de Köppen de 1961 à 2015," EchoGéo(41) (2017) [doi:10.4000/echogeo.15017].

32. NASA, "Tropical Rainfall Measuring Mission (TRMM)" (2020).

33. T. X. Bastos et al., "Características agroclimáticas do município de Paragominas," Folhetos Embrapa Amaz. Orient.(228), 24 (2005).

34. F. Laurent et al., "Soil texture derived from topography in North-eastern Amazonia," J. Maps 13(2), 109-115 (2016).

35. B. Kotschoubey, W. Truckenbrodt, and J. M. C. Calaf, "Evolução geológica da porcão meridional da província bauxitífera de Paragominas, durante o Neógeno/Pleistoceno (Noroeste da Bacia do Grajaú, nordeste do Pará e extremo oeste do Maranhão)," Rev. Bras. Geoc 35, 263-272 (2005).

36. A. Pinto et al., "Diagnóstico socioeconômico e florestal de Paragominas," Instituto do Homem e Meio Ambiente da Amazônia - Imazon, Belém/PA, p. 65 (2009).

37. R. Osis, F. Laurent, and R. Poccard-Chapuis, "Spatial determinants and future land use scenarios of Paragominas municipality, an old agricultural frontier in Amazonia," J. Land Use Sci. 14(3), 258-279 (2019) [doi:10.1080/1747423X.2019.1643422].

38. M. G. Piketty et al., "Multi-level Governance of Land Use Changes in the Brazilian Amazon: Lessons from Paragominas, State of Pará," Forests 6(5), 1516-1536 (2015) [doi:10.3390/f6051516].

39. B. Kotschoubey, W. Truckenbrodt, and B. Hieronymous, "Depósitos de caolim e argila semi-flint no nordeste do Pará," Rev. Bras. Geoc 26, 71-80 (1996). 
40. T. Iguchi et al., "Rain-Profiling Algorithm for the TRMM Precipitation Radar," J. Appl. Meteorol. 39(12), 2038-2052 (2000) [doi:10.1175/1520-0450(2001)040<2038:RPAFTT>2.0.CO;2].

41. C. Kummerow et al., "The Tropical Rainfall Measuring Mission (TRMM) Sensor Package," J. Atmospheric Ocean. Technol. 15(3), 809-817 (1998) [doi:10.1175/15200426(1998)015<0809:TTRMMT>2.0.CO;2].

42. V. M. Mantas et al., "Validation of TRMM multi-satellite precipitation analysis (TMPA) products in the Peruvian Andes," Atmospheric Res. 163, 132-145 (2015) [doi:10.1016/j.atmosres.2014.11.012].

43. NASA, "MODIS Vegetation Index Products (NDVI and EVI)" (2020).

44. Huete, A.R. et al., "Overview of the radiometric and biophysical performance of the MODIS vegetation indices," Remote Sens. Environ. 83(1-2), 195-213 (2002).

45. Kuhn, M., caret: Classification and Regression Training. R package version 6.0-41. http://CRAN.Rproject.org/package=caret (2015).

46. Liaw, A. and Wiener, M., "Classification and Regression by randomForest," R News $\mathbf{2 / 3}, 18-22$ (2002).

47. Perrier, F., "Caractérisation et cartographie de l'éco-efficience des pâturages amazoniens à l'aide d'images MODIS," Université du Maine, Le Mans (France), p. 65 (2014).

48. T. B. McKee, N. J. Doesken, and J. Kleist, "The relationship of drought frequency and duration of time scales," presented at Eighth Conference on Applied Climatology, American Meteorological Society, Jan 17-23, 1993, Anaheim CA, 179-186.

49. B. B. N. Strassburg et al., "When enough should be enough: Improving the use of current agricultural lands could meet production demands and spare natural habitats in Brazil," Glob. Environ. Change 28, 84-97 (2014) [doi:10.1016/j.gloenvcha.2014.06.001].

50. M. Grimaldi et al., "Ecosystem services of regulation and support in Amazonian pioneer fronts: searching for landscape drivers," Landsc. Ecol. 29(2), 311-328 (2014) [doi:10.1007/s10980-0139981-y].

51. T. E. Rodrigues et al., "Caracterização e Classificação dos Solos do Município de Paragominas, Estado do Pará," Embrapa Amaz. Orient. - Doc. 162, 1-49 (2003).

52. M. M. L. Müller et al., "Degradação de pastagens na Região Amazônica: propriedades físicas do solo e crescimento de raízes," Pesqui. Agropecuária Bras. 36(11), 1409-1418 (2001) [doi:10.1590/S0100-204X2001001100012].

53. A. AghaKouchak et al., "Remote sensing of drought: Progress, challenges and opportunities: REMOTE SENSING OF DROUGHT," Rev. Geophys. 53(2), 452-480 (2015) [doi:10.1002/2014RG000456].

54. H. S. Srivastava, P. Patel, and R. R. Navalgund, "How far SAR has fulfilled its expectation for soil moisture retrieval," presented at Asia-Pacific Remote Sensing Symposium, 1 December 2006, Goa, India, 641001 [doi:10.1117/12.693946].

55. J. Alvarez-Mozos et al., "Assessment of the operational applicability of RADARSAT-1 data for surface soil moisture estimation," IEEE Trans. Geosci. Remote Sens. 44(4), 913-924 (2006) [doi:10.1109/TGRS.2005.862248].

56. P. Patel and H. S. Srivastava, "An approach to validate soil moisture derived from passive microwave sensors using SAR as an interface," Int. J. Remote Sens. 36(9), 2353-2374 (2015) [doi:10.1080/01431161.2015.1034889].

57. H. West, N. Quinn, and M. Horswell, "Remote sensing for drought monitoring \& impact assessment: Progress, past challenges and future opportunities," Remote Sens. Environ. 232, 111291 (2019) [doi:10.1016/j.rse.2019.111291]

58. Y. Malhi et al., "Climate Change, Deforestation, and the Fate of the Amazon," Science 319(5860), 169-172 (2008) [doi:10.1126/science.1146961]. 